\title{
PENYUSUNAN MODEL PROGRAM CORPORATE SOCIAL RESPONSIBILITY (CSR) DI PERGURUAN TINGGI KOTA SALATIGA DALAM UPAYA MENINGKATKAN INTAKE PERGURUAN TINGGI
}

\author{
Lina Sinatra Wijaya \\ Program Studi Public Relations Fakultas Teknologi Informatika \\ Universitas Kristen Satya Wacana Salatiga \\ lina.sinatra@staff.uksw.edu \\ Krismiyati \\ Program Studi Pendidikan Teknik InformatikaFakultas Teknologi Informatika \\ Universitas Kristen Satya Wacana Salatiga \\ krismiyati@staff.uksw.edu
}

\begin{abstract}
Corporate Social Responsibility (CSR) is one of the promotion techniques done by a Public Relations in higher education institutions to face the tougher competition among the higher education institution in gaining new students. Most higher education institutions in Salatiga try to do some CSR programs to achieve their goal. This study tries to investigate what suitable model of CSR done by higher education institutions in Salatiga-Central Java which is also implemented and the influence of this program to students' intake in one academic year. Lastly, it tries to propose a CSR modeling for increasing students' intake at higher education Institution in Salatiga-Central Java. This study employs interview and literature study for data collection. The data are then analyzed qualitatively to answer the posed research questions. This study involved 7 Higher education institutions in Salatiga-Central Java and also 19 High schools which are spread in 7 cities in Central Java. The result of the study shows that the Public Relations unit in each higher education institutions has carried out their CSR program to some of the Schools in Central Java, but lack of coordination done by both parties. However they emphasize their CSR program focusing on community service, high school student activities, scholarships and training. In order to effectively achieve the goal, an intake cycled relations model is proposed.
\end{abstract}

Keywords: CSR, higher education institutions 


\section{PENDAHULUAN}

Dalam era globalisasi sekarang ini, aktifitas perang promosi bahkan perang tarif dalam menjajakan sebuah perguruan tinggi sering sekali kita lihat. Semua ini dilakukan dalam rangka mempertahankan eksistensi suatu perguruan tinggi. Untuk menarik minat calon mahasiswanya, Perguruan Tinggi Swasta (PTS) setiap tahun akan melakukan berbagai cara promosi yang dilakukannya secara rutin baik melalui media cetak maupun media elektronik serta hal hal yang lain dari presentasi sampai roadshow ke daerah-daerah dan pelosok-pelosok bahkan mengikuti pameranpameran pendidikan serta melakukan presentasi-presentasi dan lain-lain, yang bersifat mempromosikan program studi-program studi yang ada di universitasnya masing-masing.

Dari fenomena diatas, maka suatu perguruan tinggi harus melakukan promosinya dengan menggunakan strategi yang lain dari yang lain supaya hasil yang dicapai bisa maksimal. Salah satunya adalah menggunakan pendekatan Public Relations $(P R)$ yang dirancang dengan menyiapkan program pendekatan yang lebih menonjolkan keterlibatan universitas dalam memberikan pengabdiannya kepada masyarakat sekitar atau kepada stakeholdernya, dalam hal ini adalah SMA-SMA yang menjadi target sasarannya. Program pengabdian masyarakat ini yang sering disebut Corporate Social Responsibility (CSR) inilah yang sekarang ini dibutuhkan oleh SMA-SMA tersebut. Masuknya bidang $P R$ ke dalam perancanaan program promosi khususnya melalui program $C S R$ akan lebih mengena ke dalam ingatan siswa siswa SMA dari pada hanya sekedar mendengarkan presentasi maupun menghadiri pameran-pameran pendidikan.Ini dikarenakan dalam pelaksanaan program CSR ini, para siswa dapat merasakan kualitas dari perguruan tinggi tersebut serta poin-poin positif yang dimiliki perguruan tinggi tersebut, yang berimbas pada peningkatan kepercayaan target sasaran terhadap perguruan tinggi tersebut.

\section{RUMUSAN MASALAH}

Perumusan masalah dari penelitian ini adalah program kegiatan CSR yang seperti apa yang sesuai untuk dilakukan oleh institusi perguruan tinggi di SalatigaJawa Tengah. Adapun hasil yang diharapkan dalam penelitian ini adalah:

1. Akan dihasilkan model program Corporate Social Responsibility (CSR) di perguruan tinggi KotaSalatiga yang aplikabel dan efektif dalam upaya peningkatan intake perguruan tinggi dimana model ini diharapkan dapat digunakan sebagai petunjuk bagi praktisi Public Relations $(P R)$ di perguruan tinggi dalam merancang, melaksanakan dan mengevaluasi metoda promosi yang sudah digunakan di perguruan tinggi.

2. Penyusunan model program Corporate Social Responsibility (CSR) di perguruan tinggi Kota Salatiga yang aplikabel dan efektif dalam upaya 
peningkatan intake perguruan tinggi belum pernah dilakukan. Oleh karena itu, penelitian ini diharapkan dapatmenghasilkan model Corporate Social Responsibility (CSR) dari perguruan tinggi Kota Salatiga yang aplikabel dan efektif agar dapat meningkatkan intake mahasiswa.

3. Kajian tentang model program Corporate Social Responsibility (CSR) di perguruan tinggi di Salatiga yang aplikabel dan efektif diharapkan dapat membantu institusi perguruan tinggi dalam merancang, melaksanakan dan mengevaluasi metoda promosinya dalam upaya meningkatkan intake perguruan tinggi.

\section{KAJIAN PUSTAKA}

\section{Penelitian yang Mendahului}

Sebuah perguruan tinggi dituntut untuk memberikan kontribusi yang nyata dalam pemecahan masalah-masalah sosial yang ada dalam masyarakat demi terciptanya masa depan yang berkelanjutan. Program CSR juga telah diterapkan di sepuluh universitas besar dunia (Nejatiet al., 2011). Mereka menegaskan bahwa semua universitas yang mereka libatkan dalam penelitian telah melaksanakan program $C S R$ dalam berbagai bidang dan skala. Dalam hal ini, peranan program $C S R$ mereka anggap sebagai bagian dari upaya perguruan tinggi untuk menunjukkan akuntabilitas dan kredibilitas mereka ditengah kehidupan masyarakat. Ini juga merupakan suatu upaya pencitraan bagi sebuah perguruan tinggi. Terlihat jelas di sini bahwa peranan sebuah Perguruan Tinggi telah berevolusi dari sebuah lembaga akademik yang hanya memberikan layanan akademis menjadi sebuah lembaga yang peka terhadap keberadaan dan kondisi lingkungan dan masyarakat.

Seiring dengan adanya evolusi peranan perguruan tinggi dalam masyarakat, program $C S R$ dirasa sangat diperlukan bagi eksistensi sebuah perguruan tinggi. Bagi perguruan tinggi swasta, program ini dapat dimanfaatkan sebagai strategi untuk memperoleh reputasi yang bagus di tengah masyarakat (Dahan dan Senol 2012). Dalam penelitian mereka, Dahan dan Senol (2012) menyimpulkan bahwa program CSR yang berhasil menciptakan citra dan reputasi yang baik dalam masyarakat adalah program $C S R$ yang berhasil diinternalisasi dengan baik serta didukung penuh oleh pihak manajemen perguruan tinggi. Selain itu program $C S R$ yang dilaksanakan oleh perguruan tinggi memiliki keuntungan ganda, bermanfaat bagi masyarakat yang menerima manfaat dan kontribusinya dan juga sangat berguna bagi perguruan tinggi itu sendiri melalui efek pencitraan yang diterimanya.

Selain berperan dalam membentuk reputasi dan pencitraan sebuah perguruan tinggi, program $C S R$ merupakan sarana untuk bersaing dengan para kompetitornya. Program $C S R$ juga menunjukkan dimana letak platformperguruan tinggi sesungguhnya. Yang dimaksudkan disini adalah bahwa dalam program CSR memuat 
secara implisit ke arah manakah sebuah perguruan tinggi dalam masyarakat akan dibawa, apakah hanya murni sebagai lembaga yang berkecimpung dalam dunia akademis semata atau memang mampu menyumbangkan kontribusi yang nyata dan bermanfaat bagi masyarakat (Topal 2009)

Melihat pentingnya program $C S R$ bagi perguruan tinggi, tentu saja program CSR tidak bisa dilepaskan dari Public Relations. Kedua hal ini sangat berkaitan erat, dalam artian, program CSR merupakan bagian dari Public Relations yang perlu dilaksanakan oleh perguruan tinggi guna memantapkan posisi dan eksistensinya dalam masyarakat dan pada akhirnya berimbas pada pencitraan. Program CSR bisa menguatkan dan membangun hubungan yang kuat antara perguruan tinggi dengan para stakeholder dan juga masyarakat secara umum (Goodwin and Bartlett 2008).

\section{Corporate Social Responsibility (CSR)}

Menurut Wineberg dan Rudolph (2004)defineCSR adalah sebagai berikut: "CSR is the contribution that a company makes in society through its core business activities, its social investment and philanthropy programs and its engagement in public policy" (Wineberg 2004:72). Selanjutnya dikatakan oleh Schermerhon (1993) bahwa CSR adalah merupakan suatu kepedulian organisasi bisnis untuk bertindak dengan cara-cara mereka sendiri dalam melayani kepentingan organisasi dan kepentingan public eksternal. Sedangkan Kotler dan Lee (2005) mengatakan bahwa CSR is a commitment to improve community well being through discretionary business practices and contribution of corporate resources. Pendapat dari Pramuningtyas sedikit berbeda. Dia mengatakan bahwa $C S R$ adalah akuntabilitas atas segala tindakan perusahaan dalam mempengaruhi orang-orang, masyarakat dan lingkungan sekitar perusahaan berada (Pramuningtyas 2005). Nuryana mengatakan sedikit berbeda lagi, dia mengatakan bahwa CSR adalah sebuah pendekatan dimana perusahaan mengintegrasikan kepedulian sosial dalam operasi bisnis mereka dan dalam interaksi mereka dengan para pemangku kepentingan (stakeholders) berdasarkan prinsip kesukarelaan dan kemitraan (Nuryana 2005)

Berdasarkan beberapa definisi-definisi diatas dapat dilihat adanya kesamaan bahwa CSR perusahaan atau institusi merupakan suatu kepedulian sosial terhadap masyarakat di lingkungan suatu perusahaan/institusi dan bersifat mempengaruhi orang-orang disekitar institusi untuk mempunyai citra yang baik terhadap institusi/perusahaan mereka dan dalam pekerjaannya mengutamakan kepentingan stakeholdersnya, berdasarkan prinsip kesukarelaandan kemitraan bukan ditekankan.

\section{PerkembanganCSRdi Indonesia}

Indonesia merupakan negara yang subur dan kaya akan hasil buminya, tetapi kekayaan ini tidak dapat dimanfaatkan dengan baik oleh masyarakat Indonesia, sehingga kekayaan yang kita miliki ini tidak dapat mensejahterakan masyarakat Indonesia. Bangsa Indonesia belum bisa memanfaatkan secara penuh akan kekayaan yang dimiliki ini. Kondisi ini dimanfaatkan oleh bangsa lain yang mulai 
menanamkan modalnya di Indonesia, bahkan bisa dikatakan sekaligus mengambil kekayaan alam yang dimiliki oleh bangsa Indonesia ini. Kondisi ini benar benar mengawatirkan kita. Karena kekawatiran inilah maka kemudian muncul gerakan gerakan atau usaha usaha untuk menyelamatkan bumi bagi keberlangsungan kehidupan manusia di masa yang akan datang.

Kalau dilihat dari sisi perusahaan/institusi, pada kenyataannya sekarang ini kemampuan perusahaan untuk bersaing sangat tergantung pada keadaan/lokasi dimana perusahaan/institusi tersebut berada. Oleh karena itu, piramida CSR yang dikembangkan oleh Archie B. Carrol (dalam Tanudjaya 2006) harus bisa dipahami sebagai satu kesatuan, sebab CSR merupakan kepedulian perusahaan yang didasari tiga prinsip dasar yang diikenal dengan istilah triple bottom lines yaitu profit, people and planet $(3 P)$, yaitu sebagai berikut.

a. Profit

Perusahaan tetap harus berorientasi untuk mencari keuntungan ekonomi yang memungkinkan untuk terus beroperasi dan berkembang.

b. People

Perusahaan harus memiliki kepedulian terhadap kesejahteraan manusia, salah satunya mengembangkan program CSR seperti pemberian beasiswa bagi pelajar sekitar perusahaan, pendirian sarana pendidikan dan kesehatan, penguatan kapasitas ekonomi lokal dan bahkan ada perusahaan yang merancang berbagai skema perlindungan sosial bagi warga setempat.

c. Planet

Perusahaan peduli terhadap lingkungan hidup dan keberlangsungan keragaman hayati. Beberapa program $C S R$ yang berpijak pada prinsip ini biasanya berupa penghijauan lingkungan hidup, penyediaan sarana air bersih, perbaikan pemukiman, pengembangan pariwisata (ekoturisme) (Porter 2005:5)

Sehingga suatu perusahaan tidak akan bisa berkembang jika menutup mata atau tidak mau peduli dengan situasi dan kondisi lingkungan sosial dimana perusahaan itu berada. Oleh karena itulah penerapan CSR dirasakan sebagai suatu keharusan yang harus dilakukan oleh perusahaan. CSR bukan saja sebagai tanggung jawab, tetapi juga sebagai kewajiban (Tanudjaya 2006)

\section{Model Corporate Social Responsibility (CSR)}

Menurut Saidi dan Hamid (2004) ada empat model/pola yang umum diterapkan oleh perusahaan di Indonesia antara lain sebagai berikut.

a. Keterlibatan langsung.

Dalam hal ini perusahaan menjalankan program $C S R$ secara langsung dengan menyelenggarakan secara langsung dengan menyelenggarakan sendiri kegiatan sosial atau menyerahkan sumbangan ke masyarakat tanpa perantara.

b. Melalui yayasan atau organisasi sosial perusahaan.

Perusahaan mendirikan yayasan sendiri dibawah perusahaan atau groupnya. 
c. Bermitra dengan pihak lain.

Perusahaan menyelenggarakan CSR melalui kerja sama dengan lembaga sosial/organisasi non pemerintah (NGO/LSM), instansi pemerintah, universitas atau media massa, baik dalam mengelola dana maupun dalam melaksanakan kegiatan sosialnya.

d. Mendukung atau bergabung dengan suatu konsorsium.

Perusahaan turut mendirikan,menjadi anggota atau mendukung suatu lembaga sosial yang didirikan untuk tujuan sosial tertentu. Pola ini lebih berorientasi pada pemberian hibah perusahaan yang bersifat "hibah pembangunan".

Hardinsyah et al. (2005) dalam Suharti (2008), bedah buku Kotler dan Lee yang diterbitkan pada tahun 2005, dengan judul Corporate Social Responsibility, Doing the most good for you company and Your cause, oleh Roy Goni. Dalam buku tersebut mengidentifikasikan ada enam bentuk CSR (http://www.kompas.com).

a. Cause promotion dalam bentuk memberikan kontribusi dana atau penggalangan dana untuk meningkatkan kesadaran akan masalah masalah sosial tertentu seperti, bahaya narkotika.

b. Caused-related marketingbentuk kontribusi perusahaan dengan menyisihkan sepersekian persen dari pendapatan sebagai donasi bagi masalah sosial tertentu, untuk atau produk tertentu.

c. Corporate social marketing, perusahaan membantu pengembangan maupun implementasi dari kampanye dengan fokus untuk merubah perilaku tertentu yang mempunyai pengaruh negatif.

d. Corporate philantrophy adalah inisiatif perusahaan dengan memberikan kontribusi langsung kepada suatu aktivitas amal, lebih sering dalam bentuk donasi ataupun sumbangan tunai.

e. Community volunteering dalam aktivitas ini perusahaan memberikan bantuan dan mendorong karyawan, serta mitra bisnisnya untuk secara sukarela terlibat dan membantu masyarakat setempat.

f. Socially responsible business practices, ini adalah sebuah inisiatif dimana perusahaan mengadopsi dan melakukan praktisi bisnis tertentu serta investasi yang ditunjukkan untuk meningkatkan kualitas komunitas dan melindungi lingkungan.

\section{Konsep Intake}

Kata intake menurut Hornby(1995) dalam Oxford Advance Learner's Dictionary berarti a number of people entering an institution, etc during a particular period (Sekelompok orang yang masuk ke dalam suatu institusi dalam kurun waktu tertentu). Dari definisi ini dapat disimpulkan bahwa yang dimaksud dengan intake dalam penelitian ini adalah jumlah mahasiswa baru yang masuk ke perguruan tinggi dalam tahun akademik tertentu. Sedangkan untuk mengetahui peningkatan intake 
akan dilihat dari banyaknya jumlah mahasiswa yang registrasi ulang pada perguruan tinggi tersebut dalam tahun akademik tertentu.

\section{Model yang akan Menjadi Acuan}

Menurut Hanneman dan Riddle (2005), dalam sebuah jaringan yang terbentuk dalam masyarakat ada salah satu tipe yang dinamakan dengan "cycle network $^{\text {ee }}$. Cycle network atau jaringan yang berbentuk siklus ini mengacu pada sebuah bentuk jaringan yang mungkin dibentuk dalam masyarakat yang berinteraksi dan masing-masing aktor dalam jaringan tersebut saling berhubungan satu dengan yang lain. Senada dengan pendapat tersebut, Scott (2000) menjelaskan bahwa siklus yang berhasil dibentuk tersebut tidak terbatas jumlah aktornya. Hal ini menunjukkan bahwa bisa saja dalam satu siklus terdapat tiga, empat dan seterusnya. Arah hubungan dalam jejaring seperti ini juga bukan merupakan satu hal yang mutlak harus pada satu arah, bisa saja terjadi hubungan timbal balik antar aktor atau juga hubungan yang saling berkesinambungan menuju arah tertentu. Lihat Gambar 1.

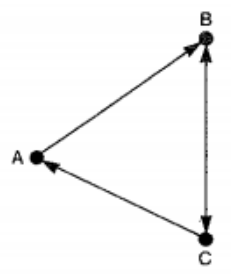

Kemungkinan Arah Hubungan dalam Cycle Networkdengan Tiga dan Empat Node

Komponen yang penting dalam cycle network ini adalah siklus yang terjadi. Siklus yang mungkin terjadi bergantung pada jumlah aktor atau "node" dalam jaringan tersebut. Dalam Gambar 1, terlihat ada tiga dan empat node yang terlibat dalam pembentukan jaringan yang ada. Cycle network dengan tiga node atau aktor biasa juga disebut sebagai triads (Carringtonet al., 2005). Jumlah node yang membentuk suatu jaringan tidak terbatas jumlahnya dan masih bisa membuat suatu cycle. Dalam model ini terdapat aktor-aktor atau node disertai dengan hubungan yang terbentuk seperti terlihat dalam gambar.Masing-masing garis menunjukkan hubungan atau tie yang dibentuk dalam cycle network. Hubungan atau tie tersebut bisa kuat ataupun lemah sesuai dengan arah yang terbentuk dalam jaringan (Wasserman dan Faust 1994). 


\section{METODA PENELITIAN}

\section{Jenis Penelitian}

Penelitian ini bersifat penelitian deskriptif artinya hasil penelitian disampaikan dalam bentuk deskripsi yang bersifat kualitatif. Analisis kualitatif digunakan untuk menjelaskan dan memahami fenomena tentang apa yang dialami oleh subjek penelitian misalnya persepsi, motivasi, tindakan dengan cara deskripsi dalam bentuk kata-kata dan bahasa pada suatu konteks yang alamiah dan dengan memanfaatkan berbagai metoda alamiah (Moleong 2006:6). Selain itu, penelitian ini juga bersifat eksploratif karena penelitian ini berusaha menggali program Corporate Social Responsibility $(C S R)$ yang bagaimana yang cocok diterapkan di perguruan tinggi di Salatiga (Jawa Tengah).

\section{Lokasi Penelitian}

Lokasi penelitian ini dipilih secara sengaja yaitu dilakukan kota Salatiga, untuk Perguruan Tingginya sedangkan untuk mengetahui program apa yang sesuai dengan target pasar dalam hal ini SMA-SMA yang menjadi target sasaran dari perguruan tinggi tersebut, maka kami akan mengunjungi beberapa SMA yang ada di Jawa Tengah khususnya Salatiga, Ambarawa, Ungaran, Boyolali, Solo, Semarang dan Kudus.Sejauh ini kami telah mendatangi tujuh perguruan tinggi dan 19 sekolah yang ada di Jawa Tengah untuk menggalang data yang dipergunakan dalam penelitian ini.

\section{Teknik Pengumpulan Data}

Data primer diperoleh dari wawancara dengan bagian-bagian terkait dengan kegiatan promosi di perguruan tinggi di Salatiga dalam hal ini Public Relations officer dengan berpedoman pada instrumen penelitian menggunakan teknik interview, survei, observasi dan Focus Group Discussion (FGD). Data diperoleh dari interview langsung diterapkan kepada responden, dalam hal ini perguruan tinggi yang terletak di Salatiga.

Selain itu kami juga sudah mengunjungi 19 SMA-SMK yang sudah kami tentukan untuk mengetahui program CSR yang seperti apa yang dibutuhkan oleh sekolah yang nantinya kami harapkan akan mempengarui citra perguruan tinggi tersebut yang akan berimbas pada peningkatan intake.

\section{Teknik Pengambilan Sampel}

Populasi dari penelitian ini adalah perguruan tinggi di Salatiga (Jawa Tengah) dan SMA-SMK di Jawa Tengah. Sampel yang digunakan sebagai unit analisis akan diambil dengan menggunakan teknik simple random sampling, yaitu suatu teknik pengambilan sampel dengan metoda acak tanpa memperhatikan strata (tingkatan) dalam anggota populasi tersebut. Setiap unit anggota populasi mempunyai kesempatan yang sama untuk terpilih menjadi anggota sampel. 


\section{HASIL PENELITIAN}

\section{Program CSR yang Dilakukan oleh Perguruan Tinggi}

Dari hasil interview yang kami lakukan menunjukkan bahwa sebagian besar perguruan tinggi melakukan berbagai macam model pengabdian masyarakat. Program pengabdian masyarakat atau yang lebih dikenal dengan Corporate Social Responsibility (CSR) yang dilakukan biasanya disesuaikan dengan target sasaran yang dituju. Program CSR yang dilakukan diharapkan dapat berimbas pada intake nantinya.

Tabel 1

Jenis/Macam Program CSR yang Ditawarkan Perguruan Tinggi

\begin{tabular}{ll}
\hline \multicolumn{1}{c}{ Perguruan Tinggi } & \multicolumn{1}{c}{ Jenis/Macam Program CSR } \\
\hline PT 1, PT 2 dan PT 3 & $\begin{array}{l}\text { Dengan memberi pelatihan kepada masyarakat melalui UKM yang } \\
\text { ada dan pelayanan kepada masyarakat setempat. }\end{array}$ \\
PT 4, PT 5, PT 6 dan PT 7 & $\begin{array}{l}\text { Dengan mengajarkan beberapa mata pelajaran di SMA dan juga } \\
\text { memberi pelatihan kepada guru dan staf administrasi sekolah. }\end{array}$ \\
PT 7 & Dengan memberi beasiswa kepada siswa SMA. \\
\hline
\end{tabular}

\section{Program CSR yang diperoleh oleh Sekolah}

Dari hasil interview yang kami lakukan terhadap 12 sekolah sejauh ini menunjukkan bahwa sebagian besar sekolah belum pernah mengajukan program pengabdian masyarakat ke perguruan tinggi. Beberapa dari mereka bahkan ada yang belum pernah mendapatkan program $C S R$ dari perguruan tinggi, meskipun ada pula yang sudah mendapatkan dan bahkan meminta untuk keberlangsungannya setiap tahun.

Dari 19 sekolah tersebut hampir semua menekankan bahwa tidak ada komunikasi sebelumnya sehingga mereka tidak tahu bahwa program CSR ini sebenarnya bisa diajukan oleh sekolah ke perguruan tinggi. Mereka selama ini cenderung menunggu kalau ada tawaran. Mereka merasa kalau ini merupakan suatu program pengabdian masyarakat, seharusnya pihak perguruan tinggi yang menawarkan sehingga birokrasinya tidak akan serumit bila mereka mengajukan.Adapun hasil dari interview yang didapatkan dapat terlihat dalam Tabel 2.

Dari hasil yang didapat sejauh ini telah didapatkan bahwa dalam mencari tahu apa yang diperlukan/program CSR yang seperti apa yang diperlukan oleh target sasaran, serta apa yang perguruan tinggi lakukan untuk menjaga keberlangsungan program ini, ada dua hal yang perlu diingat yaitu sebagai berikut, (1) kita sebagai public relations dari perguruan tinggi perlu "mendengarkan dan merespon" (listen and respond) apa yang diperlukan oleh target sasaran; (2) Apa yang sudah dilakukan tersebut perlu dilakukan secara berkesinambungan (sustainability) sehingga hubungan antara perguruan tinggi dengan sekolah akan semakin baik. 
Tabel 2

Masukan Program CSRuntuk Sekolah

\begin{tabular}{|c|c|c|}
\hline SMA/SMK & Mengajukan Penawaran & Usulan \\
\hline HS $1,3,6,9,17$ & Ya & $\begin{array}{l}\text { Sebaiknya program CSR berganti-ganti } \\
\text { setiap tahunnya, Birokrasinya di } \\
\text { sederhanakan. }\end{array}$ \\
\hline HS 2, 4, 5, 7, 14, 16 & Tidak & $\begin{array}{l}\text { Dikomunikasikan terlebih dahulu selama ini } \\
\text { hanya berdasarkan penwaran dan terkadang } \\
\text { penawaran tidak sesuai dengan yang } \\
\text { diharapkan. }\end{array}$ \\
\hline HS $8,11,13$ & Tidak & $\begin{array}{l}\text { Sebaiknya dari PT mengajukan penawaran, } \\
\text { karena sekolah merasa sungkan apabila } \\
\text { harus meminta sesuatu tanpa harus } \\
\text { mengeluarkan biaya. }\end{array}$ \\
\hline HS $12,10,15,17,18$ & Tidak & $\begin{array}{l}\text { Belum pernah mendapatkan sama sekali } \\
\text { sebaiknya diinfokan cara kerjanya dan } \\
\text { bagaimana agar bisa dimanfaatkan oleh } \\
\text { sekolah. }\end{array}$ \\
\hline
\end{tabular}

Apabila kedua hal ini telah dilakukan maka secara tidak langsung akan meningkatkan intake dari perguruan tinggi tersebut. Karena sekolah secara tidak langsung pula akan menyarankan/mengarahkan siswanya untuk masuk ke perguruan tinggi yang telah memberikan program CSRdi sekolah tersebut.

\section{PEMBAHASAN}

Dari hasil interview yang sudah dilakukan baik di perguruan tinggi maupun di sekolah, sudah dapat dilihat bahwa semua perguruan tinggi atau pendidikan tinggi di Salatiga telah melakukan program CSR (Corporate Social Responsibility) yang dikemas dalam bentuk kegiatan kegiatan yang berbeda beda. Prinsip kerja seorang public relations dalam suatu institusi perguruan tinggi yang sekarang marak dilakukan oleh pendidikan tinggi antara lain adalah melakukan program CSR yang yang akan melibatkan semua personal di dalam perguruan tinggi tersebut juga langsung dilakukan ke target sasaran. Ini sesuai dengan prinsip triple bottom line CSRyang juga dicetuskan oleh Suharti (2007)dimana dikatakan bahwa suatu perusahaan dalam hal ini bisa kita katakan suatu perguruan tinggi/pendidikan tinggi yang ingin tetap bertahan, sebaiknya tidak hanya mengejar profit semata, tapi harus juga terlibat dalam pemenuhan kesejahteraan masyarakat (people) serta berpartisipasi dalam menjaga kesejahteraan lingkungannya (planet).

Hubungan yang berkesinambungan terlihat jelas dalam program program CSR yang ditawarkan yang diharapkan dapat memberikan keuntungan dari kedua belah pihak. Oleh karena itu keterlibatan langsungyang merupakan suatu salah satu model yang diterapkan di perusahaan di Indonesia (Saidi 2004) ataupun suatu pendidikan tinggi dalam melaksanakan kegiatan CSR ini sangat penting untuk 
memberikan bantuan langsung kepada masyarakat sehingga masyarakat akan mengetahui kualitas dari perguruan tinggi tersebut. Ini terlihat dimana salah satu perguruan tinggi di Salatiga (PT 1) melakukan kegiatan langsung dengan memberikan bantuan dalam pengelolaan UKM di masyarakat yang menjadi target sasarannya. Selain itu juga ada perguruan tinggi yang bermitra dengan alumninya(Saidi 2004) dalam rangka menyempurnakan program kerja mereka.

Keterlibatan pendidikan tinggi dalam menjalin hubungan dengan para stakeholdernya tidak terlepas dari peran public relations dalam menerapkan program CSR di lembaga pendidikan tersebut. Oleh karena itu, para SMA maupun SMK juga diharapkan akan dapat mengajukan program CSR ini ke perguruan tinggi, sehingga masyarakat tahu kondisinya seperti apa.

Semua kegiatan yang dilakukan oleh public relations ini terutama dalam pengaturan kegiatan program CSR sangatlah menarik dan dapat meningkatkan taraf hidup masyarakat yang menjadi sasarannya, selain itu bagi perguruan tinggi akan berimbas pada peningkatan intake, dikarenakan citra Universitas Kristen Satya Wacana yang baik yang akan mendorong masyarakat masuk ke perguruan tinggi tersebut.

Dari interview yang di lakukan kepada beberapa pedoman yang perlu dilakukan oleh perguruan tinggi antara lain (Sinatra dan Krismiyati 2014) adalah (1) mendengarkan dan merespon, hal ini perlu dilakukan oleh sebuah perguruan tinggi, karena tanpa mendengar apa yang sebenarnya dibutuhkan oleh sekolah, maka perguruan tinggi tidak tahu program apa yang tepat dan harus dilakukan dan setelah mengetahui apa yang dibutuhkan oleh sekolah, maka perguruan tinggi wajib meresponnya dengan rencana yang sudah dibuat. Poin yang paling penting dalam pedoman ini adalah keberlanjutan dalam pelaksanaan program CSR ini. Karena tanpa keberlanjutan, maka tidak akan berpengaruh besar terhadap intake pada perguruan tinggi tersebut.

Berdasarkan data dan analisa yang disajikan dalam penetitian ini, maka disimpulkan bahwa suatu model program kerja CSR dalam upaya meningkatkan intake dari perguruan tinggi. Dalam pola kerja dari program CSR ini seharusnya bagus, sehingga saling berkoordinasi antara perguruan tinggi dengan sekolah sangatlah diperlukan sehingga akan mendapatkan program kerja CSR nya baik. Diharapkan dengan penerapan program $C S R$ yang sudah sesuai dengan apa yang diinginkan masyarakat maupun calon mahasiswa baru, maka akan sangat berpengaruh pada intake dari perguruan tinggi tersebut.

\section{Intake Cycled Relations Model}

Model yang dihasilkan dalam penelitian ini berpijak pada teori cycle network (Hanneman dan Riddle 2005; Scott 2000, Scott dan Wasserman 2005). Berdasarkan konsep cycle network yang berfokus pada tiga aktor atau node serta hubungan atau tie yang dibentuk, node yang dimaksud dapat terdiri dari empat node maka model 
Corporate Social Responsibility bagi perguruan tinggi di Salatiga ini dinamakan intake cycled Relations Model. Alasan pemakaian nama "intake" mengarah pada tujuan dari kegiatan ini adalah peningkatan intake dari perguruan tinggi tersebut, Model yang mengadaptasi adanya empat node dan tie, yang kekuatan hubungannya mendukung satu sama lainnya. Kata "cycled" digunakan untuk menunjukkan bahwa hubungan antara node satu dengan yang lain saling menopang dan merupakan simbol dari suatu siklus kegiatan. Pemodelan Corporate Social Responsibility bagi perguruan tinggi di Salatiga dalam upaya meningkatkan intake bisa digambarkan sebagai berikut.

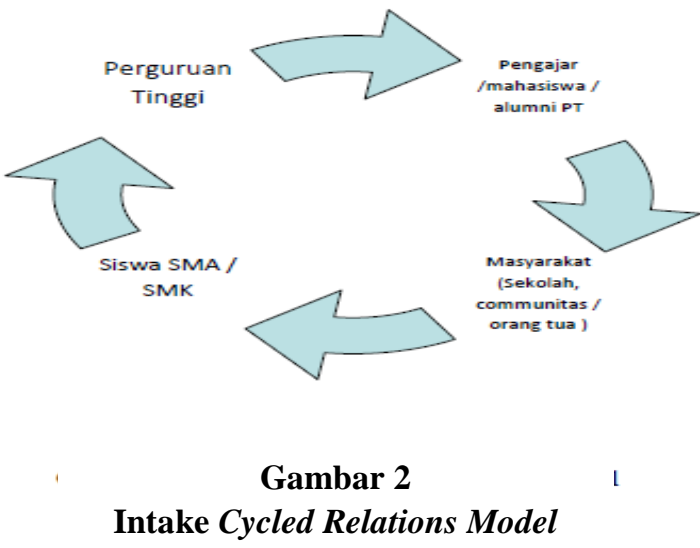

Adapun unsur empat node yang terlibat dalam model tersebut adalah, perguruan tinggi, alumni/mahasiswa dari perguruan tinggi, masyarakat (Sekolah/komunitas sekitar/orangtua) dan selanjutnya adalah siswa SMA/SMK sebagai tujuan utama/sasaran dari kegiatan ini, yang akhirnya akan berimbas pada kenaikan intake di perguruan tinggi tersebut. Perguruan tinggi dalam model ini memiliki peran sebagai pemrakarsa yang bisa menawarkan program CSR yang bisa menjawab kebutuhan masyarakat, sebagai salah satu stake holder dari institusi pendidikan, perguruan tinggi biasanya menggunakan mahasiswa/pengajar perguruan tinggi tersebut atau alumni/dari perguruan tinggi tersebut dalam melakukan program CSR nya. Perguruan tinggi dan masyarakat/sekolah bisa bersinergi dengan menerapkan prinsip "listen and respond" (Sinatra dan Krismiyati 2014). Dengan mendengarkan apa yang menjadi kebutuhan stake holdernya, perguruan tinggi bisa merencanakan dan menawarkan program yang betul-betul tepat sasaran. Sementara itu, unsur yang ketiga, yaitu masyarakat/sekolah yang telah memberikan gambaran program seperti apa yang mereka butuhkan, akan mendapatkan program yang sesuai dan bisa merasakan dampaknya. Tentu saja, setelah masyarakat/sekolah merasakan dampak dari program CSR yang dilakukan, masyarakat biasanya secara tidak langsung memiliki kewajiban moral untuk mengarahkan ataupun memberi saran yang menjurus kepada satu perguruan tinggi yang telah berjasa kepada mereka. Pendapat, saran dan arahan masyarakat atau sekolah ini biasanya akan berpengaruh 
terhadap node yang ke empat yaitu siswa SMA/SMK sebagai calon-calon mahasiswa baru di sebuah perguruan Tinggi. Setelah kedua pihak ini saling mendukung pada masing-masing tahap dalam siklus yang ada, langsung ataupun tidak langsung akan berdampak pada intake sebuah perguruan tinggi. Nantinya setelah intake tersebut diproses dalam institusi pendidikan ini, maka akan kembali membuahkan programprogram yang bisa bermanfaat bagi masyarakat.Proses ini terus berlanjut berulangulang selama proses perekrutan mahasiswa terus dilaksanakan setiap tahunnya. Dengan sinergi yang baik, maka keempat unsur dalam model intake cycled relations dapat menjawab permasalahan ketidakpastian dan ketidakjelasan program CSR di beberapa perguruan tinggi yang ada di Salatiga.

\section{SIMPULAN DAN IMPLIKASI}

Semua perguruan tinggi yang terlibat dalam penelitian ini telah melaksanakan program CSR ke target sasarannya. Setiap institusi dalam penelitian ini memiliki lembaga atau bagian yang menangani pelaksanaan program CSR ini. Dalam pelaksanaannya, perguruan tinggi ini melibatkan pengajar, mahasiswa serta alumni dari perguruan tinggi tersebut.

Program-program CSR yang sudah direncanakan dan dilaksanakan sebagian besar cukup efektif dalam meningkatkan intake mahasiswa. Namun demikian, satu hal yang tidak bisa dipungkiri oleh masing-masing perguruan tinggi adalah perlunya mendengar dan kemudian merespon apa yang sebenarnya diinginkan oleh target sasaran. Apabila target sasaran, dalam hal ini sekolah sekolah/masyarakat sekitar, sudah mendapatkan hal tersebut, kontinuitas keberlangsungan program tersebut harus dijaga. Diharapkan dengan mendapatkan program $C S R$ yang diinginkan, maka secara tidak langsung akan mempengaruhi sekolah untuk mengarahkan siswanya ke perguruan tinggi tersebut dan semua ini secara tidak langsung akan meningkatkan intake dari perguruan tinggi tersebut.

\section{DAFTAR PUSTAKA}

Carrington,P., J. Scott, dan Wasserman. 2005. Models and Methods in Social Network Analysis Cambridge. Cambridge University Press.

Dahan, G. S., dan I.Senol. 2012. Corporate social responsibility in higher education institutions: Istanbul bilgi university case. American International Journal of Contemporary Research. Vol.2 No.3.

Goodwin, F. W., dan J. L. Bartlett. 2008. Public relations and corporate social responsibility (CSR). Working Paper. Available athttp://eprints.qut.edu. 
Hanneman, R. A., dan Riddle, M. 2005. Introduction to social network methods. Riverside, CA: University of California, Riverside. Available athttp://faculty.ucr.

Hornby, A. S.1995. Oxford Advanced Learner's Dictionary, Oxford: Oxford University Press, Fifth Edition.

Nejati, M., A. Shafaei, dan M. Daraei.2011. Corporate social responsibility and universities: A study of top 10 world universities. Academic Journals. Available at http://www.academicjournals.org.

Moleong, J. L. 2006.Metodologi Penelitian Kualitatif: Edisi Revisi. Bandung: Remaja Rosdakarya.

Nuryana, M. 2005. Corporate social responsibility dan kontribusi bagi pembangunan berkelanjutan. makalah yang disampakkan pada Diklat Pekerjaan Sosial Industri, Balai Besar Pendidikan dan Pelatihan Kesejahteraan Sosial (BBPPKS) Bandung, Lembaga 5 Desember.

Porter, M. E., dan R. K. Mark. 2002. The competitive advantage of corporate Philantrophy dalam Harvard Business Review, Desember.

Pramuningtyas, I. 2005. Tanggung jawab sosial perusahaan pada PT Batik Tjokrohadi Surakarta.Skripsi Program S1 Fakultas Ekonomi Universitas Kristen Satya Wacana.

Scott, J. 2000.Social Network Analysis: A Handbook. London: Sage Publication Ltd.

Sinatra, L., dan Krismiyati. 2014. General rule of thumb of CSR program to increase intake in higher education.Jurnal of Arts, Science \& Commerce-Researchers World. Vol.5 No.3.

Saidi, Z., dan A. Hamid. 2004. Menjadi Bangsa Pemurah: Wacana dan Praktek kedermawaan Sosial di Indonesia. Jakarta: Piramedia.

Suharti, L., dan A. Donafin. 2008.Corporate Social Responsibility (CSR): Teori dan Praktek. Fakultas Ekonomi: Universitas Kristen Satya Wacana Salatiga.

Tanudjaya, B. B. 2006. Perkembangan corporate social responsibility di Indonesia. Jurnal Nirmala. Vol.8. No.2 (July): 92-98.

Topal, R.2009. CSR in Universities Around the World. Social Responsibility Research Network.

Wasserman, S., dan K. Faust. 1994. Social Network Analysis Methods and Application. New York: Cambridge University Press.

Wineberg, D., dan H. R. Phillip. 2004.Corporate Social Responsibility - What every in House counsel should know dalam ACC Docket. 